\title{
Sources of black carbon aerosols in South Asia and surrounding regions during the Integrated Campaign for Aerosols, Gases and Radiation Budget (ICARB)
}

\author{
R. Kumar ${ }^{1,2}$, M. C. Barth ${ }^{2}$, V. S. Nair ${ }^{3}$, G. G. Pfister ${ }^{2}$, S. Suresh Babu ${ }^{3}$, S. K. Satheesh ${ }^{4}$, K. Krishna Moorthy ${ }^{5}$, \\ G. R. Carmichael ${ }^{6}$, Z. Lu $^{7}$, and D. G. Streets ${ }^{7}$ \\ ${ }^{1}$ Advanced Study Program, National Center for Atmospheric Research, Boulder, USA \\ ${ }^{2}$ Atmospheric Chemistry Division, National Center for Atmospheric Research, Boulder, USA \\ ${ }^{3}$ Space Physical Laboratory, Vikram Sarabhai Space Center, Thiruvanantpuram, India \\ ${ }^{4}$ Centre for Atmospheric and Oceanic Sciences, Indian Institute of Science, Bangalore, India \\ ${ }^{5}$ Indian Space Research Organization (HQ), New BEL Road, Bangalore, India \\ ${ }^{6}$ Center for Global and Regional Environmental Research, University of Iowa, Iowa City, IA 52242, USA \\ ${ }^{7}$ Energy Systems Division, Argonne National Laboratory, Argonne, IL 60439, USA
}

Correspondence to: R. Kumar (rkumar@ucar.edu)

Received: 24 August 2014 - Published in Atmos. Chem. Phys. Discuss.: 10 December 2014

Revised: 18 March 2015 - Accepted: 25 April 2015 - Published: 19 May 2015

\begin{abstract}
This study examines differences in the surface black carbon (BC) aerosol loading between the Bay of Bengal (BoB) and the Arabian Sea (AS) and identifies dominant sources of $\mathrm{BC}$ in South Asia and surrounding regions during March-May 2006 (Integrated Campaign for Aerosols, Gases and Radiation Budget, ICARB) period. A total of $13 \mathrm{BC}$ tracers are introduced in the Weather Research and Forecasting Model coupled with Chemistry to address these objectives. The model reproduced the temporal and spatial variability of $\mathrm{BC}$ distribution observed over the $\mathrm{AS}$ and the BoB during the ICARB ship cruise and captured spatial variability at the inland sites. In general, the model underestimates the observed BC mass concentrations. However, the model-observation discrepancy in this study is smaller compared to previous studies. Model results show that ICARB measurements were fairly well representative of the $\mathrm{AS}$ and the $\mathrm{BoB}$ during the pre-monsoon season. Elevated $\mathrm{BC}$ mass concentrations in the $\mathrm{BoB}$ are due to 5 times stronger influence of anthropogenic emissions on the BoB compared to the AS. Biomass burning in Burma also affects the BoB much more strongly than the AS. Results show that anthropogenic and biomass burning emissions, respectively, accounted for 60 and $37 \%$ of the average \pm standard deviation (representing spatial and temporal variability) $\mathrm{BC}$ mass concentration $\left(1341 \pm 2353 \mathrm{ng} \mathrm{m}^{-3}\right)$
\end{abstract}

in South Asia. BC emissions from residential (61\%) and industrial $(23 \%)$ sectors are the major anthropogenic sources, except in the Himalayas where vehicular emissions dominate. We find that regional-scale transport of anthropogenic emissions contributes up to $25 \%$ of $\mathrm{BC}$ mass concentrations in western and eastern India, suggesting that surface BC mass concentrations cannot be linked directly to the local emissions in different regions of South Asia.

\section{Introduction}

Black carbon (BC), a byproduct of incomplete combustion, is a key atmospheric aerosol species because it contributes largely to the climate forcing (e.g., Ramanathan and Carmichael, 2008; Wang et al., 2014; Hodnebrog et al., 2014) and, along with other fine particulates, adversely affects human health (e.g., Dockery and Stone, 2007). BC is emitted from various sources including industries, motor vehicles, power plants, residential solid biofuel burning and open biomass burning of forests, savannas and crop residues. The total global emissions of BC aerosol estimated using bottomup approaches are $7500 \mathrm{Gg} \mathrm{yr}^{-1}$ in the year 2000 with an uncertainty range of 2000 to $29000 \mathrm{Gg} \mathrm{yr}^{-1}$ (Bond et al., 2013). 
$\mathrm{BC}$ has very low chemical reactivity in the atmosphere and is removed primarily by the wet and dry depositions at the surface. However, the wet deposition represents $70-85 \%$ of the global total loss (Pöschl, 2005). The average atmospheric lifetime of $\mathrm{BC}$ is estimated to be about 1 week (Bond et al., 2013), enabling BC aerosols to undergo regional and intercontinental transport.

Different emission sources of $\mathrm{BC}$ show strong regional variations (Lawrence and Lelieveld, 2010; Lu et al., 2011; Bond et al., 2013); South Asia, with its large population density involved in a wide range of human activities, is considered to be one of the hotspots of $\mathrm{BC}$ emissions (Bond et al., 2007). In addition, different emission inventories show an increasing trend in $\mathrm{BC}$ emissions over South Asia (Granier et al., 2011). Large emissions of BC in South Asia lead to BCinduced radiative perturbation which is significantly higher than the globally averaged estimates (Babu et al., 2004; Ramanathan and Carmichael, 2008). Model estimates show that this forcing has the potential to affect the Asian summer monsoon (Ramanathan et al., 2005; Lau et al., 2006) and Himalayan glaciers (e.g., Menon et al., 2010; Yasunari et al., 2010).

Many efforts have been made to measure BC mass concentration, document its diurnal, seasonal and spectral (absorption) characteristics and estimate local-scale BC-induced radiative perturbation in a wide range of atmospheric conditions (urban, rural, marine and high-altitude mountains) in South Asia (e.g., Satheesh and Ramanathan, 2000; Babu et al., 2004; Beegum et al., 2009; Gustafsson et al., 2009; Nair et al., 2008, 2013; Marrapu et al., 2014). The regional- and global-scale radiative impacts of $\mathrm{BC}$ and other short-lived pollutants emitted from different sectors have also been estimated in some global modeling studies (e.g., Reddy et al., 2005; Unger et al., 2009, 2010; Verma et al., 2011). However, the relative contributions of different emission sources to atmospheric BC mass concentrations are still unknown for South Asia, except for the Delhi region where the majority of the atmospheric BC is attributed to emissions from transportation $(\sim 59 \%)$ and domestic $(\sim 32 \%)$ sectors (Marrapu et al., 2014).

Chemical transport models serve as our primary tool for establishing the relation between the amount of an emitted species and its atmospheric concentration. However, a detailed evaluation of such models is required before conducting such an analysis. In this study, we first evaluate the performance of the Weather Research and Forecasting Model (Skamarock et al., 2008) coupled with Chemistry (WRFChem) (Grell et al., 2005; Fast et al., 2006) using highresolution BC measurements made as a part of the Integrated Campaign for Aerosols, Gases and Radiation Budget (ICARB) (Moorthy et al., 2008). The evaluation exercise also provides confidence in using the model for future studies. The evaluated WRF-Chem configuration is then used to answer the following two questions: (a) why is aerosol loading higher over the Bay of Bengal (BoB) compared to the Ara- bian Sea (AS)? (b) What were the most important sources of surface BC aerosols in South Asia during the ICARB? It is important to answer the first question because the stronger aerosol radiative forcing over the Bay of Bengal has been suggested to affect the monsoonal circulation and rainfall over South Asia (Bollasina et al., 2013). The answer to the second question has implications for improving air quality in South Asia, but we need to extend this analysis to multiple years to account for long-terms change in the aerosol emissions and meteorology. This study focuses only on the ICARB period. Source contribution analysis for 1 complete year is discussed in a separate paper (Kumar et al., 2015). To answer the above questions, we introduce source-, sectorand region-specific BC tracers in WRF-Chem.

We begin with a description of ICARB observations, WRF-Chem configuration and implementation of BC tracers in the WRF-Chem. In the Results section, we first evaluate the model performance and then quantify the contribution of different emission sources and sectors to total BC loading and demonstrate the importance of regional transport in distribution of BC in the atmosphere of South Asia.

\section{Experimental design}

We use version 3.5.1 of the WRF-Chem model to simulate the geographical distribution of BC in South Asia and surrounding regions. Recently, we set up WRF-Chem over South Asia and demonstrated that WRF-Chem is able to capture observed variations in meteorology (Kumar et al., 2012a), gas-phase chemistry (Kumar et al., 2012b, 2013) and dust aerosols (Kumar et al., 2014a, b) over South Asia. However, the model's ability to simulate BC in South Asia and surrounding regions has not been tested so far. In this study, we attempt to fill this gap by comparing WRF-Chem simulated $\mathrm{BC}$ with extensive measurements of $\mathrm{BC}$ made over the Bay of Bengal and the Arabian Sea during 18 March-11 May 2006 during ICARB (see Fig. 1 for ship track) (Moorthy et al., 2008) and average BC values reported at 12 inland stations in the model domain. ICARB was an integrated multiinstrument, multi-platform field campaign and provided extensive co-located measurements of several aerosol parameters and trace gases over the Bay of Bengal, the northern Indian Ocean and the Arabian Sea. ICARB observations revealed large spatiotemporal heterogeneities in several aerosol parameters including the $\mathrm{BC}$ mass concentrations and trace gases over the oceanic regions around India (Moorthy et al., 2008; Nair et al., 2008; Srivastava et al., 2012).

During the ocean segment of ICARB, a special laboratory was configured at the top deck of the ship called "Sagar Kanya" and ambient air was drawn from a height of about $10 \mathrm{~m}$ above the water level into various instruments deployed for measurements of trace gases and aerosols. BC mass concentrations were measured using an Aethalometer (AE 21 by Magee Scientific) operated at a time base of $5 \mathrm{~min}$ and flow 


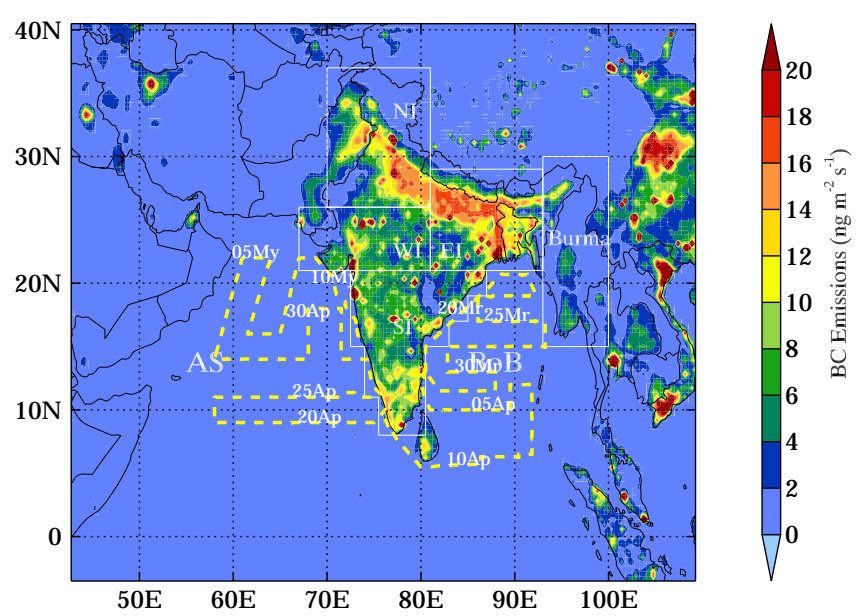

Figure 1. Spatial distribution of anthropogenic BC emissions over the model domain. Different regions from which $\mathrm{BC}$ emissions are tagged are shown with the Bay of Bengal and the Arabian Sea. Yellow line represents the ICARB ship track, with the number standing for day of Month: Mr (March), Ap (April) and My (May). NI, WI, EI and SI represent north, west, east and south India, respectively.

rate of $5 \mathrm{~L} \mathrm{~min}^{-1}$. The ship sailed in the BoB and the northern Indian Ocean from 9 March to 13 April 2006 and in the AS from 18 April to 11 May. The meteorological conditions prevailing during the ICARB were composed mainly of calm synoptic conditions with weak winds, clear skies and absence of precipitation (except for 9 April). The ship did not face any major weather system or cyclonic depression during the whole campaign. Analysis of synoptic-scale wind patterns showed the presence of weak westerly winds in the northern BoB associated with a low-level anticyclonic circulation centered at $88^{\circ} \mathrm{E}, 15^{\circ} \mathrm{N}$, and weak easterly winds prevailed south of $12^{\circ} \mathrm{N}$ in the BoB. During the AS segment of the campaign, the synoptic winds were strong westerlies in the northern AS which turned sharply to northerlies close to the peninsular India due to the presence of a strong anticyclone at $60^{\circ} \mathrm{E}, 16^{\circ} \mathrm{N}$. Further details of the ship-cruise track, measurement set up, uncertainties, quality control and analysis of $\mathrm{BC}$ measurements and meteorological conditions during ICARB are discussed in Nair et al. (2008).

In addition, we use average $\mathrm{BC}$ values reported for March to May at 12 stations in the model domain (Table 1). These stations are located in a wide range of chemical environments with Delhi, Kanpur, Kharagpur and Dibrugarh representing urban/semi-urban sites, Lhasa representing a highaltitude urban site, Trivandrum representing a coastal semiurban site, Nainital, Nagarkot, Langtang and Nepal Climate Observatory - Pyramid (NCO-P) representing high-altitude cleaner sites and Minicoy and Port-Blair representing island sites, respectively.

The WRF-Chem domain covers South Asia and surrounding oceanic regions with a horizontal grid spacing of $36 \mathrm{~km}$ (Fig. 1) and 35 levels from surface to $10 \mathrm{hPa}$. Aerosol pro- cesses are represented by the Model for Simulating Aerosol Interactions and Chemistry (MOSAIC, Zaveri et al., 2008) using four size bins. MOSAIC treats black carbon as internally mixed with other major aerosol species including sulfate, nitrate, organic carbon, liquid water, methanesulfonate, chloride, carbonate, ammonium, sodium, calcium and other inorganics (including dust) within each size bin. The aerosol particles are considered hydrophilic and can activate to form cloud droplets. Aerosol particles are subjected to both dry and wet deposition (in- and below-cloud scavenging); the dry deposition module follows Binkowski and Shankar (1995) and wet deposition module follows Easter et al. (2004). Wet deposition represents the major loss $(\sim 84 \%)$ process for BC in our model domain. The gas-phase chemistry is represented by Model for Ozone and Related Tracers (MOZART) chemical mechanism (Emmons et al., 2010; Knote et al., 2014). Initial and lateral boundary conditions for meteorological and chemical fields are obtained from 6-hourly NCEP Final Analysis Fields and MOZART-4 results (Emmons et al., 2010), respectively. Analysis nudging is applied to horizontal winds, moisture and temperature above the planetary boundary layer with a nudging coefficient of $3 \times 10^{-4} \mathrm{~s}^{-1}$.

Anthropogenic emissions of $\mathrm{BC}$ and other trace species in India and regions east of India are taken from the Southeast Asia Composition, Clouds and Climate Coupling by Regional Study (SEAC ${ }^{4} \mathrm{RS}$ ) emissions inventory (Lu and Streets, 2012), while those in the regions west of India and the shipping emissions are taken from MACCity emission inventory (Granier et al., 2011). The spatial distribution of anthropogenic BC emissions is shown in Fig. 1 and shows highest values over the Indo-Gangetic Plain. The total annual anthropogenic BC emissions in this combined (SEAC ${ }^{4} \mathrm{RS}+$ MACCity) emission inventory for South Asia $\left(60-100^{\circ} \mathrm{E}, 5-37^{\circ} \mathrm{N}\right)$ are estimated as $\sim 1195 \mathrm{Gg} \mathrm{yr}^{-1}$. These emission estimates are comparable to other regional inventories such as System for Air quality Forecasting And Research India (SAFAR-India: $\sim 1110 \mathrm{Gg} \mathrm{yr}^{-1}$ ) and Regional Emission Inventory for Asia (REAS: $\sim 1170 \mathrm{Gg} \mathrm{yr}^{-1}$ ) but are significantly higher compared to Intercontinental chemical Transport Experiment Phase B inventory (INTEXB: $\left.\sim 550 \mathrm{Gg} \mathrm{yr}^{-1}\right)$. Note that SAFAR-India does not provide emissions outside India. Biomass burning emissions of trace gases and aerosols are obtained from the Fire Inventory from NCAR (Wiedinmyer et al., 2011) and are distributed in the model vertically following the online plumerise module (Freitas et al., 2007). For the nearly 2-month ICARB period (18 March-11 May 2006), total South Asian biomass burning emissions $(327 \mathrm{Gg}$ ) of $\mathrm{BC}$ are higher than the total anthropogenic emissions $(203 \mathrm{Gg})$ but $\sim 80 \%$ of the biomass burning activity occurs in Burma $\left(93-100^{\circ} \mathrm{E}\right.$, $\left.15-30^{\circ} \mathrm{N}\right)$. Note that biomass burning represents emissions only from open fires, while emissions from residential solid biofuel burning are included in the anthropogenic emissions. The parameterization used for other atmospheric processes 
Table 1. WRF-Chem simulated BC mass concentration (mean \pm standard deviation) averaged over the period of 18 March to 11 May 2006 , and observed range of average values during March-May at nine inland stations located in the model domain. The observed BC values are taken from the papers listed in the reference column.

\begin{tabular}{lrrrl}
\hline Site name & Lat, long, alt & $\begin{array}{r}\text { Mean observed } \\
\text { range (Mar-May) }\end{array}$ & $\begin{array}{r}\text { WRF-Chem } \\
(18 \mathrm{Mar}-11 \text { May 2006) }\end{array}$ & References \\
\hline Delhi & $28.6^{\circ} \mathrm{N}, 77.2^{\circ} \mathrm{E}, 260 \mathrm{~m}$ & $8-12 \mu \mathrm{g} \mathrm{m}^{-3}$ & $6.7 \pm 4.0 \mu \mathrm{g} \mathrm{m}^{-3}$ & Beegum et al. (2009) \\
Kanpur & $26.4^{\circ} \mathrm{N}, 80.3^{\circ} \mathrm{E}, 142 \mathrm{~m}$ & $2-5 \mu \mathrm{g} \mathrm{m}^{-3}$ & $4.7 \pm 2.7 \mu \mathrm{g} \mathrm{m}^{-3}$ & Ram et al. (2010) \\
Kharagpur & $22.5^{\circ} \mathrm{N}, 87.5^{\circ} \mathrm{E}, 28 \mathrm{~m}$ & $2-5 \mu \mathrm{g} \mathrm{m}^{-3}$ & $3.7 \pm 2.8 \mu \mathrm{g} \mathrm{m}^{-3}$ & Beegum et al. (2009) \\
Dibrugarh & $27.3^{\circ} \mathrm{N}, 94.6^{\circ} \mathrm{E}, 111 \mathrm{~m}$ & $5-10 \mu \mathrm{g} \mathrm{m}^{-3}$ & $3.7 \pm 3.1 \mu \mathrm{g} \mathrm{m}^{-3}$ & Pathak et al. (2010) \\
Trivandrum & $8.5^{\circ} \mathrm{N}, 76.9^{\circ} \mathrm{E}, 3 \mathrm{~m}$ & $1.8-3 \mu \mathrm{g} \mathrm{m}^{-3}$ & $0.9 \pm 0.6 \mu \mathrm{g} \mathrm{m}^{-3}$ & Beegum et al. (2009) \\
Minicoy & $8.3^{\circ} \mathrm{N}, 73.0^{\circ} \mathrm{E}, 1 \mathrm{~m}$ & $0.065-0.22 \mu \mathrm{g} \mathrm{m}^{-3}$ & $0.24 \pm 0.15 \mu \mathrm{g} \mathrm{m}^{-3}$ & Beegum et al. (2009) \\
Port-Blair & $11.6^{\circ} \mathrm{N}, 92.7^{\circ} \mathrm{E}, 60 \mathrm{~m}$ & $1.3-1.8 \mu \mathrm{g} \mathrm{m}^{-3}$ & $0.7 \pm 0.8 \mu \mathrm{g} \mathrm{m}^{-3}$ & Beegum et al. (2009) \\
Nainital & $29.4^{\circ} \mathrm{N}, 79.5^{\circ} \mathrm{E}, 1958 \mathrm{~m}$ & $0.8-1.5 \mu \mathrm{g} \mathrm{m}^{-3}$ & $1.2 \pm 0.8 \mu \mathrm{g} \mathrm{m}^{-3}$ & Beegum et al. (2009) \\
Nagarkot & $27.7^{\circ} \mathrm{N}, 85.5^{\circ} \mathrm{E}, 2150 \mathrm{~m}$ & $1.5 \mu \mathrm{g} \mathrm{m}^{-3}$ & $1.3 \pm 1.1 \mu \mathrm{g} \mathrm{m}^{-3}$ & Carrico et al. (2003) \\
Lhasa & $29.7^{\circ} \mathrm{N}, 91.1^{\circ} \mathrm{E}, 3663 \mathrm{~m}$ & $2-3 \mu \mathrm{g} \mathrm{m}^{-3}$ & $0.42 \pm 0.25 \mu \mathrm{g} \mathrm{m}^{-3}$ & Zhang et al. (2008) \\
Langtang & $28.1^{\circ} \mathrm{N}, 85.6^{\circ} \mathrm{E}, 3920 \mathrm{~m}$ & $0.5 \mu \mathrm{g} \mathrm{m}^{-3}$ & $0.8 \pm 0.5 \mu \mathrm{g} \mathrm{m}^{-3}$ & Carrico et al. (2003) \\
NCO-P & $28.0^{\circ} \mathrm{N}, 86.8^{\circ} \mathrm{E}, 5079 \mathrm{~m}$ & $0.2-0.4 \mu \mathrm{g} \mathrm{m}^{-3}$ & $0.46 \pm 0.39 \mu \mathrm{g} \mathrm{m}^{-3}$ & Bonasoni et al. (2010) \\
\hline
\end{tabular}

Table 2. Parameterization used for selected atmospheric processes in WRF-Chem.

\begin{tabular}{ll}
\hline Process & Parameterization \\
\hline Cloud microphysics & Morrison double moment (Morrison et al., 2009) \\
Radiation & RRTMG short- and long wave (Iacono et al., 2008) \\
Surface layer & MM5 similarity scheme (Beljaars, 1994) \\
Land surface model & Noah land surface (Tewari et al., 2004) \\
Planetary boundary layer & Yonsei university scheme (Hong et al., 2006) \\
Cumulus parameterization & Grell-3-D (Grell and Devenyi, 2002) \\
Gas-phase chemistry & MOZART (Emmons et al., 2010; Knote et al., 2014) \\
Photolysis & Fast Troposphere Ultraviolet Visible (Tie et al., 2005) \\
Dry deposition & Wesely (Wesely, 1989) \\
Wet deposition & Neu and Prather (Neu and Prather, 2012) \\
Biogenic emissions & MEGAN (Guenther et al., 2006) \\
Dust emissions & GOCART (Ginoux et al., 2001) \\
\hline
\end{tabular}

along with schemes used for the biogenic and dust emissions are listed in Table 2.

This study implements 13 BC tracers in the WRF-Chem model to track BC emitted from different source types, sectors and regions. The tracer approach has been used previously in WRF-Chem to study the budget of CO in the USA (Pfister et al., 2011; Boynard et al., 2012) and South Asia (Kumar et al., 2013), but BC tracers are implemented for the first time in the model. BC tracers are artificial species added to the simulation and experience the same transport, physical, chemical and loss processes as a standard BC particle. However, the tracers do not affect the standard model results by modifying the radiation, atmospheric processes and aerosol properties.

We account for all sources of $\mathrm{BC}$ in the model by tracking $\mathrm{BC}$ emitted from anthropogenic (BC-ANT) and biomass burning (BC-BB) sources within the domain and $\mathrm{BC}$ inflow from the lateral domain boundaries (BC-BDY). The BC-
BDY tracer includes the contribution from all BC emission sources located outside the selected domain and therefore its distribution will provide information about background $\mathrm{BC}$ levels for South Asia. In addition, we track BC emitted from residential (BC-RES), transport (BC-TRA), industrial (BCIND) and power-plant (BC-POW) sectors to estimate the contribution of different sectors to anthropogenic BC loadings. $\mathrm{BC}$ emissions from industrial, power and transportation sectors are mostly due to combustion of fossil fuels, while those from residential sectors are mostly due to biofuel combustion.

Five regional tracers track BC emitted from north, west, east and south India and from Burma (Fig. 1). Anthropogenic emissions of $\mathrm{BC}$ from outside these five regions are also tracked separately and are classified as other regions. The initial and boundary conditions for all BC tracers are set to 0 except boundary conditions for BC-BDY, which are set equal to BC from MOZART-4. The model sim- 


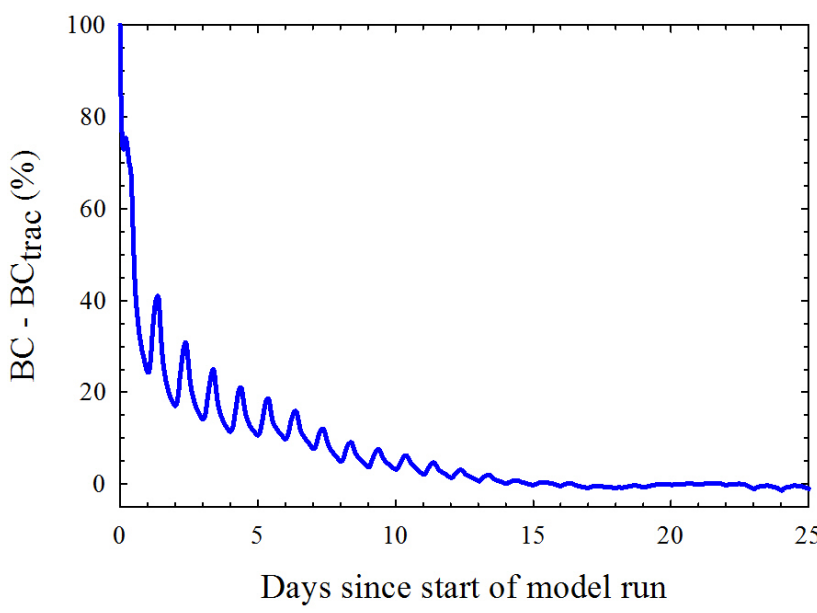

Figure 2. Time series of percentage difference between total simulated $\mathrm{BC}$ and sum of all the $\mathrm{BC}$ tracers $\left(\mathrm{BC}_{\mathrm{trac}}=\mathrm{BC}-\mathrm{ANT}+\mathrm{BC}-\right.$ $\mathrm{BB}+\mathrm{BC}-\mathrm{BDY})$.

ulations started on 15 February 2006 at 00:00 UTC with a time step of $180 \mathrm{~s}$, and model results are output every hour. The tracers are assumed to be well spun up when the sum of $\mathrm{BC}$ tracers $\left(\mathrm{BC}_{\text {trac }}=\mathrm{BC}-\mathrm{ANT}+\mathrm{BC}-\mathrm{BB}+\mathrm{BC}-\mathrm{BDY}\right)$ approaches the total simulated $\mathrm{BC}$. The time series of the relative difference between domain-wide averaged $\mathrm{BC}$ and $\mathrm{BC}_{\text {trac }}$ (Fig. 2) at the 1st, 10th and 20th model level shows that the difference rapidly approaches $0 \%$ in the first 15 days of model run and remains close to 0 for the rest of the model simulation. Thus, all tracers are spun up by 18 March 2006.

\section{Model evaluation}

We first examine the ability of WRF-Chem in reproducing the variability and features of the $\mathrm{BC}$ distribution observed over the BoB and the AS during the ICARB campaign (Nair et al., 2008). The WRF-Chem predicted BC mass concentrations (surface layer) are bi-linearly interpolated to the ICARB ship track and compared to hourly ICARB BC measurements (Fig. 3a). Both the model and observations show significantly higher $\mathrm{BC}$ levels in the $\mathrm{BoB}$ as compared to the AS. The average observed and modeled BC mass concentrations along the ship track are estimated as $755 \pm 734$ and $561 \pm 667 \mathrm{ng} \mathrm{m}^{-3}$, respectively. The underestimation of $\mathrm{BC}$ by the chemical transport models has been a common problem in this region as has been shown in several previous studies (e.g., Nair et al., 2012; Moorthy et al., 2013). However, the ratio of measured to modeled value (1.3) in our study is closer to the lower end of the range (1.4-9) of the corresponding ratios reported for marine sites in the Bay of Bengal and the Arabian Sea (Moorthy et al., 2013). The differences between WRF-Chem and observations could be related to the uncertainties in $\mathrm{BC}$ emission estimates, model transport and parameterization of aerosol processes. To eval-

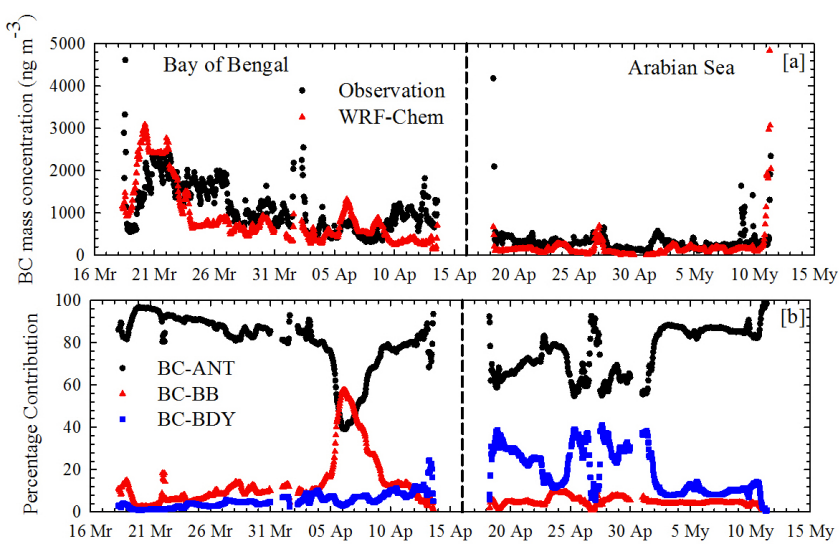

Figure 3. (a) WRF-Chem predicted and measured BC along the ICARB ship track during the ICARB period. (b) Percentage contributions of BC-ANT, BC-BB and BC-BDY to modeled BC.
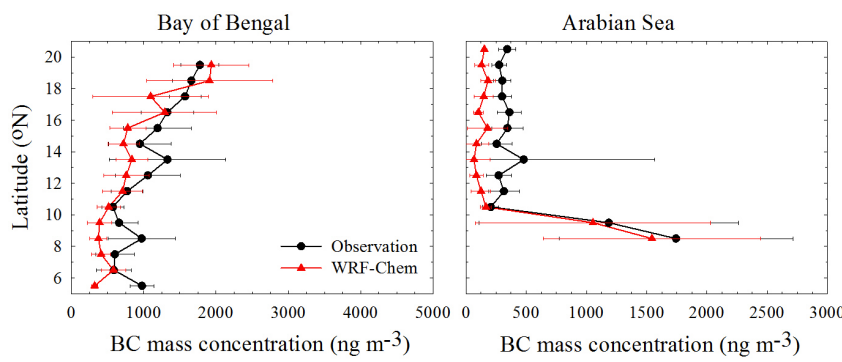

Figure 4. WRF-Chem predicted and observed latitudinal gradients in BC mass concentrations along the ICARB ship track in the Bay of Bengal and Arabian Sea regions. Horizontal bars represent $1 \sigma$ (standard deviation) variation in $\mathrm{BC}$ mass concentration averaged over a $1^{\circ}$ latitude bin.

uate the model's ability to capture the spatial variability of BC observed along the ICARB ship track, we compare colocated observed and WRF-Chem predicted latitudinal distribution of BC mass concentrations (Fig. 4). Both the model and observed values are averaged over $1^{\circ}$ latitude bins for this comparison. The model successfully captures the latitudinal gradients of opposite sense in the BoB and AS with both the model and observations showing an increasing tendency in $\mathrm{BC}$ with latitude in the BoB but a decreasing tendency in the AS. The modeled values generally match within 1 standard deviation in the Bay of Bengal and in the southern part of the Arabian Sea but are much lower north of $10^{\circ} \mathrm{N}$ in the Arabian Sea.

The ICARB observations provide only a snapshot of the $\mathrm{BC}$ distribution because the ship was moving continuously in space and time (Fig. 1). Here, we analyze the spatial distribution of $\mathrm{BC}$ mass concentrations averaged over the ICARB period (Fig. 5a) to assess the representativeness of the ICARB ship-borne observations. As for the ship observations, the average modeled spatial distribution also shows more elevated $\mathrm{BC}$ levels in the $\mathrm{BoB}$ than the AS and latitudinal gradient 

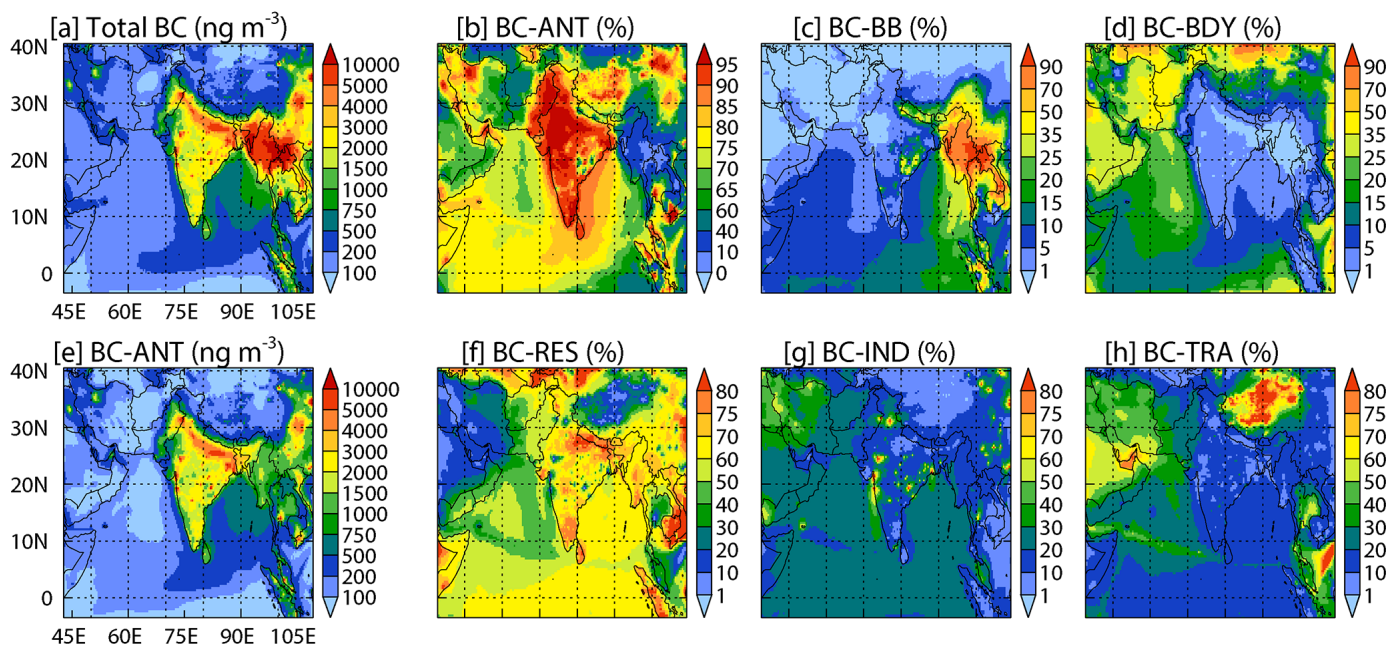

[g] BC-IND (\%)

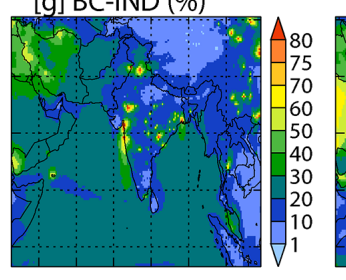

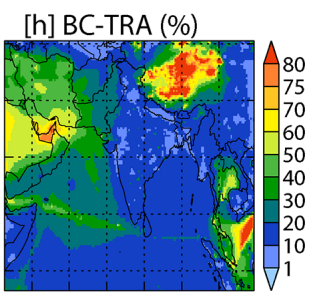

Figure 5. Spatial distributions of (a) total $\mathrm{BC}$ and (e) total anthropogenic $\mathrm{BC}$ mass concentration averaged over the ICARB period. Percentage contributions of BC-ANT (b), BC-BB (c) and BC-BDY to total BC and BC-RES (f), BC-IND (g) and BC-TRA (h) to total anthropogenic BC.

of opposite sense in the BoB and the AS. This consistency of features deduced from ICARB observations with average model results indicates that ICARB shipcruise was fairly well representative of the $\mathrm{BoB}$ and the AS during the premonsoon season.

In addition, we assess the model performance over the land by comparing WRF-Chem predicted $\mathrm{BC}$ values with average observed values reported for March to May at 12 stations in the model domain (Table 1). Average observed and modeled values at these sites range from 0.065 to 12 and 0.32 to $6.7 \mu \mathrm{g} \mathrm{m}^{-3}$, respectively. Note that the differences between the model and observations in this study are much smaller than those found in previous studies. Moorthy et al. (2013) reported that the ratio of measured to modeled (GOCART and CHIMERE) at Delhi, Kharagpur, Trivandrum, Minicoy, Port-Blair and Nainital ranged between 0.7 and 6 while the corresponding ratios in our study vary from 0.7 to 2.6 . Similarly, Nair et al. (2012) reported a ratio of $2: 5$ for different sites in India using the RegCM4 model. The largest difference between model and observations in our study was found at Lhasa (3.5), which could be related to the limited ability of the model to resolve the subgrid-scale variations in the topography and location of emission sources (roadways, power plants, industries, residential burning, etc.) at the resolution of $36 \mathrm{~km}^{2}$. Seungkyu et al. (2015, personal communication) showed that differences between the modeled and observed BC mass concentration in Kathmandu valley (an environment similar to Lhasa) can be reduced by a factor of about 4 if the emission sources are appropriately distributed according to their location as compared to the emissions averaged over grids of $5 \mathrm{~km}^{2}$. The differences between our and previous studies could be related to use of both a different emission inventory and a different chemical transport model.
The results presented above demonstrate the model's ability to simulate the $\mathrm{BC}$ distribution in this region with, however, differences in the modeled and observed BC mass concentrations. The ability of the model to capture differences in the $\mathrm{BC}$ loadings over the $\mathrm{BoB}$ and the AS with better agreement between the model and observations compared to previous studies provides confidence in using the model to understand why $\mathrm{BC}$ loading over the $\mathrm{BoB}$ is higher compared to the AS and identifying the most important sources of BC in South Asia.

\section{Results and discussion}

\subsection{Differences in BC loading over the BoB and the AS}

We first identify the sources affecting the ICARB ship track by analyzing the time series of $\mathrm{BC}$ source tracers along the ship track (Fig. 3b) to gain insight into the differences in BC loading over the $\mathrm{BoB}$ and the AS. Model results suggest that anthropogenic emissions within the model domain were the main source of $\mathrm{BC}$ observed over both the $\mathrm{BoB}$ and the $\mathrm{AS}$ during ICARB. Biomass burning emission sources did not contribute more than $10 \%$ except during 5-8 April 2006, when the contribution of biomass burning exceeded $50 \%$. The contribution of $\mathrm{BC}$ transported from the domain boundaries to the total $\mathrm{BC}$ mass concentration was less than $10 \%$ in the BoB but was up to $40 \%$ in the AS. The BC mass concentration due to anthropogenic, biomass burning and boundary sources along the ship track in the BoB are estimated to be $761 \pm 668,113 \pm 129$ and $33 \pm 5 \mathrm{ng} \mathrm{m}^{-3}$, respectively, while the corresponding values in the AS are estimated to be $149 \pm 389,7 \pm 6$ and $22 \pm 12 \mathrm{ng} \mathrm{m}^{-3}$, respectively. These numbers clearly show that higher $\mathrm{BC}$ loading in the $\mathrm{BoB}$ is 
Table 3. Near-surface mass concentration $\left(\mathrm{ng} \mathrm{m}^{-3}\right)$ of total anthropogenic BC (BC-ANT) and different anthropogenic regional BC tracers during the ICARB period along the ship track in the AS and BoB and over seven geographical regions. Percentage contribution of each tracer to BC-ANT is also given in parenthesis. All numbers are rounded off to the nearest whole number value. Numbers in bold font represent the contribution of local sources to the anthropogenic BC mass concentration of that region. BR and OT represent Burma and other regions, respectively.

\begin{tabular}{|c|c|c|c|c|c|c|c|}
\hline Region & BC-ANT $^{*}$ & BC-NI* & BC-WI* & BC-EI* & BC-SI* & $\mathrm{BC}-\mathrm{BR}^{*}$ & BC-OT $^{*}$ \\
\hline \multicolumn{8}{|c|}{ Along the ICARB ship track } \\
\hline AS & $149 \pm 389$ & $\begin{array}{l}7 \pm 6 \\
(4 \%)\end{array}$ & $\begin{array}{r}20 \pm 18 \\
(14 \%)\end{array}$ & $\begin{array}{l}4 \pm 3 \\
(3 \%)\end{array}$ & $\begin{array}{r}107 \pm 377 \\
(72 \%)\end{array}$ & - & $\begin{array}{r}10 \pm 9 \\
(7 \%)\end{array}$ \\
\hline $\mathrm{BoB}$ & $761 \pm 668$ & $\begin{array}{r}159 \pm 148 \\
(21 \%)\end{array}$ & $\begin{array}{r}98 \pm 61 \\
(13 \%)\end{array}$ & $\begin{array}{r}305 \pm 410 \\
(40 \%)\end{array}$ & $\begin{array}{r}182 \pm 23 \\
(24 \%)\end{array}$ & $\begin{array}{r}1 \pm 1 \\
(-)\end{array}$ & $\begin{array}{r}18 \pm 21 \\
(3 \%)\end{array}$ \\
\hline \multicolumn{8}{|c|}{ Geographical regions } \\
\hline North India & $1245 \pm 612$ & $\begin{array}{r}1145 \pm 592 \\
(92 \%)\end{array}$ & $\begin{array}{r}22 \pm 18 \\
(2 \%)\end{array}$ & $\begin{array}{r}54 \pm 48 \\
(4 \%)\end{array}$ & $\begin{array}{r}5 \pm 6 \\
(-)\end{array}$ & - & $\begin{array}{r}20 \pm 5 \\
(2 \%)\end{array}$ \\
\hline West India & $1679 \pm 863$ & $\begin{array}{r}256 \pm 191 \\
(15 \%)\end{array}$ & $\begin{array}{r}1261 \pm 706 \\
(75 \%)\end{array}$ & $\begin{array}{r}89 \pm 81 \\
(5 \%)\end{array}$ & $\begin{array}{r}50 \pm 37 \\
(3 \%)\end{array}$ & - & $\begin{array}{r}22 \pm 7 \\
(1 \%)\end{array}$ \\
\hline East India & $2411 \pm 898$ & $\begin{array}{r}262 \pm 120 \\
(11 \%)\end{array}$ & $\begin{array}{r}99 \pm 40 \\
(4 \%)\end{array}$ & $\begin{array}{r}1853 \pm 868 \\
(77 \%)\end{array}$ & $\begin{array}{r}148 \pm 75 \\
(6 \%)\end{array}$ & $\begin{array}{r}31 \pm 18 \\
(1 \%)\end{array}$ & $\begin{array}{r}19 \pm 6 \\
(1 \%)\end{array}$ \\
\hline South India & $1657 \pm 678$ & $\begin{array}{r}75 \pm 57 \\
(5 \%)\end{array}$ & $\begin{array}{r}195 \pm 98 \\
(12 \%)\end{array}$ & $\begin{array}{r}80 \pm 100 \\
(5 \%)\end{array}$ & $\begin{array}{r}1282 \pm 580 \\
(77 \%)\end{array}$ & - & $\begin{array}{r}25 \pm 7 \\
(1 \%)\end{array}$ \\
\hline Burma & $945 \pm 224$ & $\begin{array}{r}142 \pm 66 \\
(15 \%)\end{array}$ & $\begin{array}{r}76 \pm 31 \\
(8 \%)\end{array}$ & $\begin{array}{r}328 \pm 123 \\
(35 \%)\end{array}$ & $\begin{array}{r}97 \pm 40 \\
(10 \%)\end{array}$ & $\begin{array}{r}276 \pm 121 \\
(29 \%)\end{array}$ & $\begin{array}{r}26 \pm 20 \\
(3 \%)\end{array}$ \\
\hline AS & $102 \pm 62$ & $\begin{array}{r}12 \pm 13 \\
(11 \%)\end{array}$ & $\begin{array}{r}33 \pm 40 \\
(32 \%)\end{array}$ & $\begin{array}{l}3 \pm 3 \\
(2 \%)\end{array}$ & $\begin{array}{r}36 \pm 22 \\
(35 \%)\end{array}$ & - & $\begin{array}{l}18 \pm 9 \\
(18 \%)\end{array}$ \\
\hline $\mathrm{BoB}$ & $563 \pm 508$ & $\begin{array}{r}112 \pm 102 \\
(20 \%)\end{array}$ & $\begin{array}{r}74 \pm 36 \\
(13 \%)\end{array}$ & $\begin{array}{r}234 \pm 369 \\
(42 \%)\end{array}$ & $\begin{array}{r}114 \pm 58 \\
(20 \%)\end{array}$ & $\begin{array}{r}9 \pm 16 \\
(2 \%)\end{array}$ & $\begin{array}{r}19 \pm 6 \\
(3 \%)\end{array}$ \\
\hline
\end{tabular}

* Mean \pm sigma (standard deviation).

a result of a much stronger influence of anthropogenic emission sources on the BoB compared to the AS. BC emitted from the biomass burning sources also make a significant contribution in the BoB but not in the AS.

To understand the differences in the influence of anthropogenic emissions over the BoB and the AS, we identify the regions where anthropogenic emission sources affecting the ICARB ship track are located. Therefore, we analyze the contribution of anthropogenic sources located in different regions of the domain to the total anthropogenic BC loading along the ICARB ship track in the BoB and the AS (Table 3). The ICARB ship track in the BoB was affected by all parts of India but the highest contribution is from east India (40\%), which is the region of strongest $\mathrm{BC}$ emission in the domain (Fig. 1). In contrast, the ICARB ship track in the AS was affected mostly by south India $(\sim 72 \%)$, where average anthropogenic $\mathrm{BC}$ emission rate is about $38 \%$ lower than east India.

To examine whether the results derived along the ICARB ship track are true for the whole BoB and the AS, we analyze the contribution of different regional emission sources to anthropogenic $\mathrm{BC}$ loading in the whole $\mathrm{BoB}$ and the AS (last two rows of Table 3). For the whole BoB, we find source contributions very similar to what we found along the ship track, i.e., a significant contribution (>10\%) from all parts of India with highest contribution from east India. In contrast, the source contributions over the whole AS deviate from what we found along the ICARB ship track. South India remains the most important source region for the whole AS but the contribution reduces to $35 \%$ compared to $72 \%$ estimated along the ship track. The contribution of west India $(32 \%)$ is similar to south India for the whole AS and those of north India and other source regions are more than $10 \%$. The above analysis shows that higher BC loading observed over the $\mathrm{BoB}$ compared to the AS during ICARB is a large-scale feature and results from a much stronger (about 5 times) influence of anthropogenic and biomass burning sources over the BoB.

\subsection{Source contribution analysis for South Asia}

To identify the most important sources of BC in South Asia, we analyze the spatial distributions of percentage contributions of anthropogenic, biomass burning and boundary inflow to total BC loadings in the model domain (Fig. 5b-d). Model results show large spatial variability in average total BC mass concentrations in South Asia with the highest values (> 5000 $\mathrm{ng} \mathrm{m}^{-3}$ ) in the Indo-Gangetic Plain region, 
Table 4. Average \pm standard deviation in mass concentration $\left(\mathrm{ng} \mathrm{m}^{-3}\right)$ of total $\mathrm{BC}, \mathrm{BC}$ from anthropogenic sources (BC-ANT), from biomass burning (BC-BB), from model domain boundaries (BC-BDY) and from residential (BC-RES), industrial (BC-IND), transportation (BC-TRA) and power generation (BC-POW) emissions averaged over South Asia $\left(60-100^{\circ}\right.$ E, 5-37 $\mathrm{N}$ ) during the ICARB period (18 March-11 May). The standard deviation was calculated from all the BC values in South Asia and thus represents the spatial variability of modeled average $\mathrm{BC}$ values in South Asia.

\begin{tabular}{lrrrrrrr}
\hline Total BC & BC-ANT & BC-BB & BC-BDY & BC-RES & BC-IND & BC-TRA & BC-POW \\
\hline $1341 \pm 2353$ & $810 \pm 1179$ & $497 \pm 1919$ & $34 \pm 6$ & $497 \pm 687$ & $187 \pm 629$ & $120 \pm 134$ & $5 \pm 11$ \\
\hline
\end{tabular}

Mumbai-Pune region and Burma $\left(93-100^{\circ} \mathrm{E}, 15-30^{\circ} \mathrm{N}\right)$. The BC-ANT distribution shows that anthropogenic emissions account for $60-95 \%$ of the total surface BC over India and in the cleaner regions of the Himalayas, the BoB and the AS. Elevated BC levels over Burma are mainly (> 70\%) due to biomass burning as evident from distribution of BC-BB. Biomass burning also contributes $20-50 \%$ of BC loadings in Nepal, east India and eastern BoB. The distribution of BCBDY shows that emission sources located outside the domain contribute less than $5 \%$ to the $\mathrm{BC}$ loading over most parts of India, BoB and Burma but make a moderate contribution (up to $25 \%$ ) in the AS and the Himalayas.

The spatial distributions of BC source tracers also help us to understand why latitudinal gradients of opposite sense were observed in the $\mathrm{BoB}$ and $\mathrm{AS}$ and why $\mathrm{BC}$ showed an eastward increase north of $13^{\circ} \mathrm{N}$ in the BoB (Nair et al., 2008). The latitudinal gradients of the opposite sense were observed in the BoB and the AS because influence of anthropogenic emissions in the $\mathrm{BoB}$ decreased southwards while it increased southwards in the AS (Fig. 5b). BC showed an eastward increase north of $13^{\circ} \mathrm{N}$ because eastern $\mathrm{BoB}$ was affected by both the anthropogenic and biomass burning sources while western $\mathrm{BoB}$ was affected mostly by the anthropogenic sources (Fig. 5b and c).

The average mass concentrations of BC, BC-ANT, BC$\mathrm{BB}$ and BC-BDY in South Asia $\left(60-100^{\circ} \mathrm{E}, 5-37^{\circ} \mathrm{N}\right)$ during the ICARB period are given in Table 4 . The contributions of BC-ANT, BC-BB and BC-BDY to the average total BC mass concentrations are estimated at about 60,37 and $3 \%$, respectively. The high standard deviation of the average values reflects high spatial heterogeneity of $\mathrm{BC}$ mass concentrations.

While it is seen that anthropogenic emissions stand out as the major source of $\mathrm{BC}$ in the study domain in general, we identify the contribution of different sectors (such as residential, industrial, transportation and power generation) to total anthropogenic BC loading (Fig. 5e-h). Among the different sectors, residential emissions account for more than $60 \%$ of the anthropogenic BC loading in Nepal, Bangladesh, Burma, Sri Lanka, Pakistan and central India, while emissions from industrial sector dominate in some localized regions of north, west and east India. The dominance of residential biofuel burning sources is consistent with conclusions from previous studies in this region (e.g., Gustafsson et al., 2009). In the Himalayan regions, the transport sector (vehicular emissions) contributes $60-90 \%$ to the anthropogenic BC. BC emissions from shipping are included in the transport sector and thus we see higher contribution of transport sector in the AS compared to the BoB. The contribution of $\mathrm{BC}$ emissions from power plants is estimated to be less than $1 \%$ (not shown). The average mass concentrations of BC-RES, BC-IND, BCTRA and BC-POW in South Asia $\left(60-100^{\circ} \mathrm{E}, 5-37^{\circ} \mathrm{N}\right)$ during 18 March-11 May 2006 are given in Table 4. The emissions from residential, industrial, transport and power plant sectors contribute about $61,23,15$ and $1 \%$, respectively, to average BC-ANT mass concentrations. These contributions are very similar to the contributions of residential $(62 \%)$, industrial $(21 \%)$, transport $(16 \%)$ and power plant (1\%) sectors to total anthropogenic emissions in South Asia, indicating that surface $\mathrm{BC}$ mass concentrations are closely related to the emissions. However, we will show in the next section that such a close relation between surface BC concentrations and emissions does not exist in different regions of South Asia, because regional transport of BC makes an important contribution in different South Asian regions.

\subsection{Local vs. regional anthropogenic sources}

In this section, we examine whether surface $\mathrm{BC}$ mass concentration can also be related directly to the local BC emissions in different regions of South Asia as we saw for the whole South Asia in the previous section. To understand this, we first analyze the importance of regional transport by investigating the spatial distributions of surface $\mathrm{BC}$ emitted from anthropogenic sources located in north, west, east and south India, Burma and other regions averaged over 18 March-11 May 2006 at the surface (Fig. 6). Anthropogenic sources in northern India contribute significantly (more than $100 \mathrm{ng} \mathrm{m}^{-3}$ ) to the surface anthropogenic BC loadings in western and eastern parts of India, Burma and the $\mathrm{BoB}$, and slightly influence parts of the AS along western Indian coastline. Northern Indian sources also contribute up to $50 \mathrm{ng} \mathrm{m}^{-3}$ in the Himalayan-Tibetan plateau region, but this contribution is smaller than that from other regions $\left(50-200 \mathrm{ng} \mathrm{m}^{-3}\right)$. Analysis of diurnal variations of BC emitted from northern India and vertical wind component over the Tibetan region $\left(81-90^{\circ} \mathrm{E}, 30-35^{\circ} \mathrm{N}\right)$ showed that transport of BC from north India to the Tibetan region likely occurs through upslope winds. However, more observations 

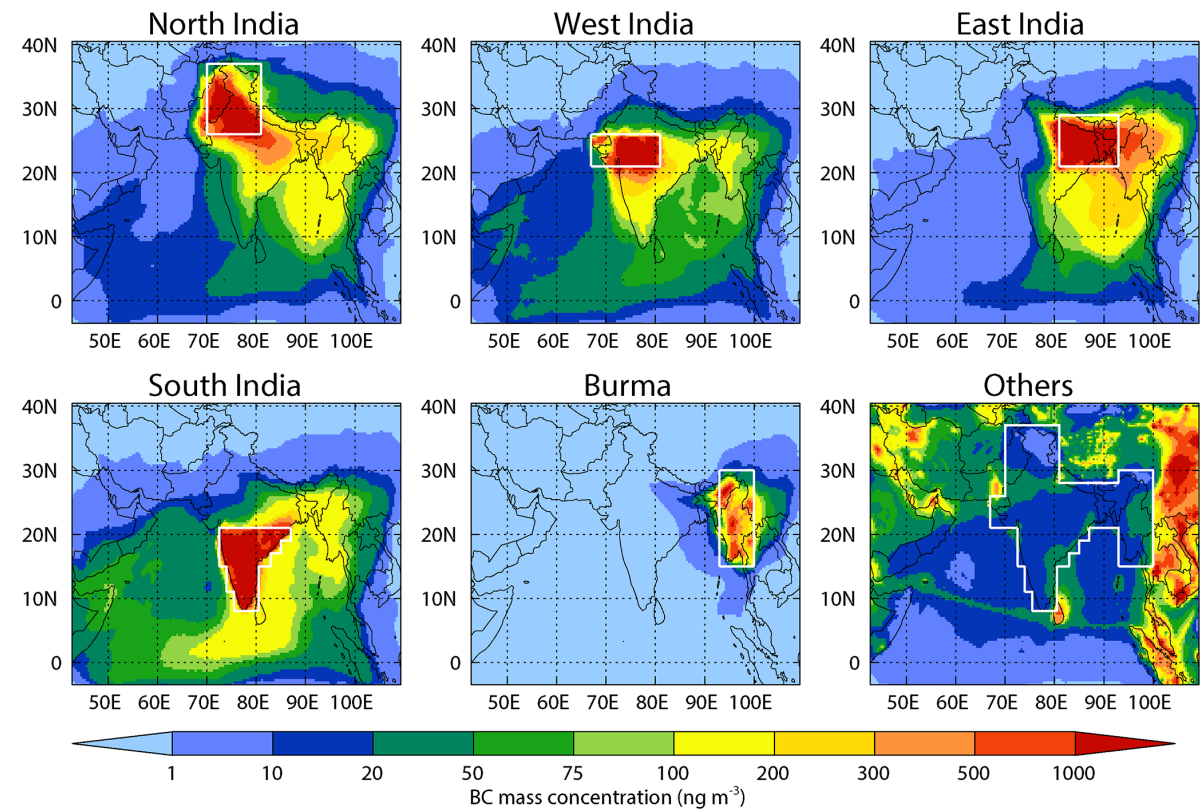

Figure 6. Spatial distributions of anthropogenic BC emitted from north, west, east and south India, Burma and other regions during the ICARB period. White solid lines mark the geographical boundaries of different regions.

and fine-scale modeling studies are required to lend further confidence in this process.

BC emitted by anthropogenic sources in western India contributes significantly to eastern and southern parts of India but the influence $\left(>50 \mathrm{ng} \mathrm{m}^{-3}\right.$ ) also reaches to the $\mathrm{BoB}$ and parts of AS along western Indian coastline. Anthropogenic sources in east India significantly affect BC loadings in Burma, Bay of Bengal and south India but the influence does not reach the AS. South Indian anthropogenic sources affect both the BoB and the AS but the influence is higher in the BoB. Anthropogenic sources located in Burma do not make a significant impact in the $\mathrm{BoB}$ and the AS, while those located in other regions affect the southern parts of the BoB near Sri Lanka.

The contributions of $\mathrm{BC}$ emitted from different regions of South Asia to the total anthropogenic BC loadings in the five defined regions of South Asia, the AS and the BoB are summarized in Table 3. Here, we also quantify the contribution of local and regional sources to the anthropogenic BC loading in the different regions. The amount of $\mathrm{BC}$ due to sources located in a given region itself (e.g., BC-NI for northern India) is defined as a contribution from local sources, and $\mathrm{BC}$ coming from sources outside this region (e.g., BC-WI + BC$\mathrm{EI}+\mathrm{BC}-\mathrm{SI}+\mathrm{BC}-\mathrm{BR}+\mathrm{BC}-\mathrm{OT}$ for northern India) is defined as contribution from the regional sources. The contribution of local sources is marked in bold font in Table 3 . Local sources account for about $90 \%$ of the anthropogenic BC loading in north and south India, but regional sources contribute up to $30 \%$ in west and $21 \%$ in east India. Regional sources make a large contribution of $75 \%$ to the an- thropogenic BC loading in Burma. However, it should also be noted that total anthropogenic $\mathrm{BC}$ loading in Burma is much smaller than the $\mathrm{BC}$ loading due to local biomass burning (Fig. 5b, c).

The above analyses clearly highlight the importance of regional transport in controlling the distribution of $\mathrm{BC}$ over South Asia. To examine whether regional transport affects the relation between local emissions and surface $\mathrm{BC}$ mass concentrations, we compare the contributions of anthropogenic and biomass burning emissions to the total $\mathrm{BC}$ emissions as well as to the surface $\mathrm{BC}$ mass concentrations in different regions of South Asia. We estimate that anthropogenic emissions contribute about $90,90,45,75$ and $3 \%$ to the total BC emissions in north, west, east and south India and in Burma, respectively, while their contributions to surface BC mass concentrations are $93,95,69,90$ and $18 \%$, respectively. Similarly, the biomass burning emissions contribute about $10,10,55,25$ and $97 \%$ of the total BC emission in north, west, east and south India and in Burma, respectively, while the contributions of biomass burning emissions to the surface $\mathrm{BC}$ mass concentrations in these regions are 4, 3, 30, 8 and $81 \%$, respectively. The sources located outside the model domain are the remaining contribution (less than $3 \%$ ) in these regions. These results show that surface $\mathrm{BC}$ concentrations cannot be inferred directly from the emission inventories in different regions of South Asia.

We further examine the contributions of residential, industrial, transport and power generation sectors to total anthropogenic emissions as well as to the surface anthropogenic BC mass concentrations in north, west, east and south In- 
Table 5. Percent contributions of residential (RES), industrial (IND), transport (TRA) and power generation (POW) sectors to the total anthropogenic emissions and to the surface anthropogenic BC mass concentrations in north (NI), west (WI), east (EI) and south India (SI) and in Burma (BR).

\begin{tabular}{lllll|llll}
\hline Region & \multicolumn{3}{c|}{$\begin{array}{c}\text { Percent contribution to } \\
\text { anthropogenic BC emissions }\end{array}$} & \multicolumn{4}{|c}{$\begin{array}{c}\text { Percent contribution to surface } \\
\text { anthropogenic BC mass concentration }\end{array}$} \\
\hline & RES & IND & TRA & POW & RES & IND & TRA & POW \\
\cline { 2 - 9 } NI & 62 & 23 & 14 & 1 & 62 & 22 & 15 & 1 \\
WI & 56 & 33 & 11 & 1 & 55 & 33 & 12 & 1 \\
EI & 70 & 19 & 10 & 1 & 68 & 20 & 11 & 1 \\
SI & 64 & 23 & 12 & 1 & 61 & 26 & 12 & 1 \\
BR & 79 & 3 & 18 & 1 & 69 & 17 & 14 & 1 \\
\hline
\end{tabular}

dia and in Burma (Table 5). It is interesting to note that the contribution of $\mathrm{BC}$ emissions from different sectors to the total anthropogenic $\mathrm{BC}$ emissions as well as to the surface anthropogenic $\mathrm{BC}$ mass concentration are very similar in north, west, east and south India despite a significant contribution (up to $25 \%$ ) of regional transport to surface total anthropogenic BC mass concentration in these regions (see Table 3). This is likely because of the fact that these geographical regions do not differ significantly in terms of the relative contribution of different sectors to total anthropogenic BC emissions, and these relative contributions are maintained during transport of $\mathrm{BC}$ from one region to the other.

In contrast, Burma is different from the Indian regions as contributions of different sectors to total anthropogenic BC emissions and to the surface anthropogenic $\mathrm{BC}$ mass concentrations are not similar. The percent contributions of different sectors to the surface anthropogenic BC mass concentrations in Burma are more similar to the Indian regions, i.e., the highest contribution is from the residential sector followed by the industrial and transport sectors. This is likely because of the fact that regional transport of $\mathrm{BC}$ from the Indian regions is the main source $(71 \%)$ of surface anthropogenic $\mathrm{BC}$ mass concentrations in Burma (see Table 5) and anthropogenic BC emissions in India are much stronger compared to Burma (see Fig. 1). These results show that it is important to account for the contribution of regional transport while relating surface $\mathrm{BC}$ concentrations to emissions, but the relationship between surface $\mathrm{BC}$ concentrations and local emissions may be preserved if emissions in the source region are weaker compared to the receptor region and relative contributions of different sectors to total emissions are similar in the source and receptor regions.

\section{Summary}

This study implemented source-, sector- and region-specific $\mathrm{BC}$ tracers in the WRF-Chem model to understand the differences in BC loadings between the Bay of Bengal and the Arabian Sea and assess the relative importance of different BC sources in South Asia during March-May 2006.
The model reproduced the temporal and spatial variability of $\mathrm{BC}$ distribution observed during the ICARB ship cruise. The average and standard deviation (representing the spatial and temporal variability) in observed and modeled BC mass concentrations along the ship track are estimated as $755 \pm 734$ and $561 \pm 667 \mathrm{ng} \mathrm{m}^{-3}$, respectively. Average modeled concentrations at most of the inland stations were also found to fall within the range of observed values. The model underestimates the observed BC mass concentrations, but model observation discrepancy in this study is found to be smaller compared to previous studies (Nair et al., 2012; Moorthy et al., 2013).

Analysis of BC tracers shows that the ICARB ship track in the BoB was affected by anthropogenic sources located in all parts of India with highest contributions from east (40\%) and south $(24 \%)$ India. In contrast, the AS was affected mostly by sources in south India. We find that elevated levels of BC in the $\mathrm{BoB}$ were due to a much stronger anthropogenic influence (5 times greater) in the BoB than the AS. Biomass burning in Burma also affects the BoB much more strongly than the AS. The features of the $\mathrm{BC}$ distribution deduced from ICARB ship observations were found to be consistent with model results averaged over larger spatial area and time period (18 March-11 May 2006) indicating that ICARB measurements were fairly well representative of the BoB and the AS during the pre-monsoon season.

Average modeled BC mass concentration in South Asia is estimated as $1341 \pm 2353 \mathrm{ng} \mathrm{m}^{-3}$ where the high standard deviation reflects the large spatial and temporal variability. Analysis of BC source tracers showed that anthropogenic emissions provided $60-95 \%$ of the total BC loading in South Asia, except in Burma where biomass burning played a major role during this period. Biomass burning also contributed more than $20 \%$ to the $\mathrm{BC}$ in Nepal, east India and eastern BoB. BC emissions from residential $(61 \%)$ and industrial $(23 \%)$ sectors are identified as major anthropogenic sources in South Asia, except in the Himalayas where vehicular emissions dominated. The transport emissions contribute up to $25 \%$ to surface BC mass concentrations in west and east India. We showed that it is important to account for the con- 
tribution of regional transport while relating surface BC concentrations to emissions in different regions of South Asia but the relationship between surface $\mathrm{BC}$ concentrations and local emissions may be preserved if emissions in the source region are weaker compared to the receptor region and/or relative contributions of different sectors to total emissions are similar in the source and receptor regions.

This study was conducted for March-May 2006 limiting our ability to extrapolate the results to other seasons or years. Kumar et al. (2015) simulated and analyzed BC seasonality for the year 2011. By comparing the March-May time period from the 2011 simulation with this current study, we can get an idea whether source attribution varies substantially between these two simulations. It should be noted that anthropogenic emissions in these two simulations are taken from two different emission inventories: $\mathrm{SEAC}^{4} \mathrm{RS}+$ MACCity emissions, the 2006 (MACCity shipping emissions and emissions due west of India) to 2012 (SEAC ${ }^{4} \mathrm{RS}$ emissions over rest of the domain) time period, for the 2006 simulation and EDGAR-HTAP emissions, which are appropriate for the 2010 time period, for the 2011 simulation. (The EDGARHTAP inventory was released after we conducted the 2006 simulation.) Therefore, differences in anthropogenic emissions between the simulations do not represent temporal changes in anthropogenic emissions appropriate for the 2 modeled years. However, the biomass burning emissions are based on the Fire Inventory from NCAR (FINN) in both the simulations and thus difference between the two simulations represents actual changes in the biomass burning emissions over this region between 2006 and 2011. In comparing the emissions from the 2006 simulation to the 2011 simulation, the anthropogenic emissions changed from about 203 to about $201 \mathrm{Gg}$, while the biomass burning emissions changed from about 327 to $285 \mathrm{Gg}$ for the ICARB period (18 March11 May). The contribution of BC-ANT, BC-BB and BCBDY to the total surface BC concentrations in the 2011 simulation are estimated as 65, 28 and $7 \%$, respectively, while the corresponding contributions in the 2006 simulations are 60,37 and $3 \%$, respectively.

This comparison shows that changes in the strength of emission sources can potentially affect the source contribution analysis, but differences in meteorology between the 2 years can also play a role. Thus, multi-year simulations accounting for temporal variability in the strength of different emission sources and variability in meteorology must be conducted before these results can be applied to design BC mitigation strategies in South Asia. The effects of seasonal change in the strength of anthropogenic and biomass burning sources the source contribution analysis of BC in South Asia are discussed in a follow-up paper (Kumar et al., 2015). Nevertheless, this study illustrates the potential of integrating in situ observations with chemical transport modeling to understand processes controlling the distribution and variability of $\mathrm{BC}$ and infer the most important sources of $\mathrm{BC}$ aerosol in a region.
Acknowledgements. We thank C. Knote for providing the basic WRF-Chem configuration used in this study. We thank F. Flocke, S. Madronich and C. Knote for their constructive comments on the manuscript. The data sets of initial and boundary conditions for meteorological fields are downloaded from http://rda.ucar.edu/datasets/ds083.2/. The data sets for initial and boundary conditions for chemical fields, biogenic emissions, biomass burning emissions and programs used to process these data sets are downloaded from the website http://www2.acd.ucar.edu/wrf-chem/. The National Center for Atmospheric Research is supported by the National Science Foundation. Authors acknowledge the ICARB project of ISRO Geosphere Biosphere Program for providing the data collected onboard Sagar Kanya. We acknowledge ECCAD science team for providing emissions data sets. Comments from two anonymous reviewers are greatly appreciated.

Edited by: H. Su

\section{References}

Babu, S. S., Moorthy, K. K., and Satheesh, S. K.: Aerosol black carbon over Arabian Sea during inter monsoon and summer monsoon seasons, Geophys. Res. Lett., 31, L06104, doi:10.1029/2003GL018716, 2004.

Beegum, S. N., Moorthy, K. K., Babu, S. S., Satheesh, S. K., Vinoj, V., Badarinath, K. V. S., Safai, P. D., Devara, P. C. S., Singh, S., Vinod, Dumka, U. C., and Pant, P.: Spatial distribution of aerosol black carbon over India during pre-monsoon season, Atmos. Environ., 43, 1071-1078, doi:10.1016/j.atmosenv.2008.11.042, 2009.

Beljaars, A. C. M.: The parameterization of surface fluxes in largescale models under free convection, Q. J. Roy. Meteor. Soc., 121, 255-270, 1994.

Binkowski, F. S. and Shankar, U.: The regional particulate matter model: 1. Model description and preliminary results, J. Geophys. Res., 100, 26191-26209, doi:10.1029/95JD02093, 1995.

Bollasina, M. A., Ming, Y., and Ramaswamy, V.: Earlier onset of the Indian monsoon in the late twentieth century: The role of anthropogenic aerosols, Geophys. Res. Lett., 40, 3715-3720, doi:10.1002/grl.50719, 2013.

Bonasoni, P., Laj, P., Marinoni, A., Sprenger, M., Angelini, F., Arduini, J., Bonafè, U., Calzolari, F., Colombo, T., Decesari, S., Di Biagio, C., di Sarra, A. G., Evangelisti, F., Duchi, R., Facchini, M. C., Fuzzi, S., Gobbi, G. P., Maione, M., Panday, A., Roccato, F., Sellegri, K., Venzac, H., Verza, G. P., Villani, P., Vuillermoz, E., and Cristofanelli, P.: Atmospheric Brown Clouds in the Himalayas: first two years of continuous observations at the Nepal Climate Observatory-Pyramid (5079 m), Atmos. Chem. Phys., 10, 7515-7531, doi:10.5194/acp-10-7515-2010, 2010.

Bond, T. C., Bhardwaj, E., Dong, R., Jogani, R., Jung, S., Roden, C., Streets, D. G., and Trautmann, N. M.: Historical emissions of black and organic carbon aerosol from energy related combustion, 1850-2000, Global Biogeochem. Cy., 21, GB2018, doi:10.1029/2006GB002840, 2007.

Bond, T. C., Doherty, S. J., Fahey, D. W., Forster, P. M., Berntsen, T., DeAngelo, B. J., Flanner, M. G., Ghan, S., Kärcher, B., Koch, D., Kinne, S., Kondo, Y., Quinn, P. K., Sarofim, S., 
Schultz, M., Venkataraman, C., Zhang, H., Zhang, S., Bellouin, N., Guttikunda, S., Hopke, P. K., Jacobson, M. Z., Kaiser, J. W., Klimont, Z., Lohmann, U., Schwarz, J. P., Shindell, D., Storelvmo, T., Warren, S. G., and Zender, S.: Bounding the role of black carbon in the climate system: A scientific assessment, J. Geophys. Res.-Atmos., 118, 1-173, doi:10.1002/jgrd.50171, 2013.

Boynard, A., Pfister, G. G., and Edwards, D. P.: Boundary layer versus free tropospheric $\mathrm{CO}$ budget and variability over the United States during summertime, J. Geophys. Res., 117, D04306, doi:10.1029/2011JD016416, 2012.

Carrico, C. M., Bergin, M. H., Shrestha, A. B., Dibb, J. E., Gomes, L., and Harris, J. M.: The importance of carbon and mineral dust to seasonal aerosol properties in the Nepal Himalayas, Atmos. Environ., 37, 2811-2824, doi:10.1016/S1352-2310(03)00197-3, 2003.

Dockery, D. W. and Stone, P. H.: Cardiovascular risks from fine particulate air pollution, New Engl. J. Med., 365, 511-513, 2007.

Easter, R. C., Ghan, S. J., Zhang, Y., Saylor, R. D., Chapman, E. G., Laulainen, N. S., Abdul-Razzak, H., Leung, L. R., Bian, X., and Zaveri, R. A.: MIRAGE: Model description and evalauation of aerosols and trace gases, J. Geophys. Res., 109, D20210, doi:10.1029/2004JD004571, 2004.

Emmons, L. K., Walters, S., Hess, P. G., Lamarque, J.-F., Pfister, G. G., Fillmore, D., Granier, C., Guenther, A., Kinnison, D., Laepple, T., Orlando, J., Tie, X., Tyndall, G., Wiedinmyer, C., Baughcum, S. L., and Kloster, S.: Description and evaluation of the Model for Ozone and Related chemical Tracers, version 4 (MOZART-4), Geosci. Model Dev., 3, 43-67, doi:10.5194/gmd3-43-2010, 2010.

Fast, J. D, Gustafson Jr., W. I., Easter, R. C., Zaveri, R. A., Barnard, J. C., Chapman, E. G., and Grell, G. A.: Evolution of ozone, particulates, and aerosol direct forcing in an urban area using anew fully-coupled meteorology, chemistry, and aerosol model, J. Geophys. Res., 111, D21305, doi:10.1029/2005JD006721, 2006.

Freitas, S. R., Longo, K. M., Chatfield, R., Latham, D., Silva Dias, M. A. F., Andreae, M. O., Prins, E., Santos, J. C., Gielow, R., and Carvalho Jr., J. A.: Including the sub-grid scale plume rise of vegetation fires in low resolution atmospheric transport models, Atmos. Chem. Phys., 7, 3385-3398, doi:10.5194/acp-7-3385-2007, 2007.

Ginoux, P., Chin, M., Tegen, I., Prospero, J. M., Holben, B., Dubovik, O., and Lin, S. J.: Sources and distributions of dust aerosols simulated with the GOCART model, J. Geophys. Res.Atmos., 106, 20255-20273, 2001.

Granier, C. Bessagnet, B., Bond, T., D’Angiola, A., van der Gon, H. G., Frost, G. J., Heil, A., Kaiser, J. W., Kinne, S., Klimont, Z., Kloster, S., Lamarque, J.-F., Liousse, C., Masui, T., Meleux, F., Mieville, A., Ohara, T., Raut, J.-C., Riahi, K., Schultz, M. G., Smith, S. J., Thompson, A., van Aardenne, J., van der Werf, G. R., and van Vuuren, D. P.: Evolution of anthropogenic and biomass burning emissions of air pollutants at global and regional scales during the 1980-2010 period, Climate Change, 109, 163-190, doi:10.1007/s10584-011-0154-1, 2011.

Grell, G. and Devenyi, A. D.: A generalized approach to parameterizing convection combining ensemble and data assimilation techniques, Geophys. Res. Lett., 29, 1693, doi:10.1029/2002GL015311, 2002.
Grell, G. A., Peckham, S. E., Schmitz, R., McKeen, S. A., Frost, G., Skamarock, W. C., and Eder, B.: Fully coupled "online" chemistry within the WRF model, Atmos. Environ., 39, 6957-6975, 2005.

Guenther, A., Karl, T., Harley, P., Wiedinmyer, C., Palmer, P. I., and Geron, C.: Estimates of global terrestrial isoprene emissions using MEGAN (Model of Emissions of Gases and Aerosols from Nature), Atmos. Chem. Phys., 6, 3181-3210, doi:10.5194/acp-63181-2006, 2006.

Gustafsson, O., Krusa, M., Zencak, Z., Sheesley, R. J., Granat, L., Engstrom, E., Praveen, P. S., Rao, P. S. P., Leck, C., and Rodhe, H.: Brown Clouds over South Asia: Biomass or Fossil Fuel Combustion?, Science, 323, 495-498, 2009.

Hodnebrog, Ø., Myhre, G., and Samset, H.: How shorter black carbon lifetime alters its climate effect, Nature Communications, 5 , 5065, doi:10.1038/ncomms6065, 2014.

Hong, S.-Y., Noh, Y., and Dudhia, J.: A new vertical diffusion package with an explicit treatment of entrainment processes, Mon. Weather Rev., 134, 2318-2341, 2006.

Iacono, M. J., Delamere, J. S., Mlawer, E. J., Shephard, M. W., Clough, S. A., and Collins, W. D.: Radiative forcing by long-lived greenhouse gases: Calculations with the AER radiative transfer models, J. Geophys. Res., 113, D13103, doi:10.1029/2008JD009944, 2008.

Knote, C., Hodzic, A., Jimenez, J. L., Volkamer, R., Orlando, J. J., Baidar, S., Brioude, J., Fast, J., Gentner, D. R., Goldstein, A. H., Hayes, P. L., Knighton, W. B., Oetjen, H., Setyan, A., Stark, H., Thalman, R., Tyndall, G., Washenfelder, R., Waxman, E., and Zhang, Q.: Simulation of semi-explicit mechanisms of SOA formation from glyoxal in aerosol in a 3-D model, Atmos. Chem. Phys., 14, 6213-6239, doi:10.5194/acp-14-6213-2014, 2014.

Kumar, R., Naja, M., Pfister, G. G., Barth, M. C., and Brasseur, G. P.: Simulations over South Asia using the Weather Research and Forecasting model with Chemistry (WRF-Chem): set-up and meteorological evaluation, Geosci. Model Dev., 5, 321-343, doi:10.5194/gmd-5-321-2012, 2012a.

Kumar, R., Naja, M., Pfister, G. G., Barth, M. C., Wiedinmyer, C., and Brasseur, G. P.: Simulations over South Asia using the Weather Research and Forecasting model with Chemistry (WRFChem): chemistry evaluation and initial results, Geosci. Model Dev., 5, 619-648, doi:10.5194/gmd-5-619-2012, 2012b.

Kumar, R., Naja, M., Pfister, G. G., Barth, M. C., and Brasseur, G. P.: Source attribution of carbon monoxide in India and surrounding regions during wintertime, J. Geophys. Res., 118, 19811995, doi:10.1002/jgrd.50134, 2013.

Kumar, R., Barth, M. C., Pfister, G. G., Naja, M., and Brasseur, G. P.: WRF-Chem simulations of a typical pre-monsoon dust storm in northern India: influences on aerosol optical properties and radiation budget, Atmos. Chem. Phys., 14, 2431-2446, doi:10.5194/acp-14-2431-2014, 2014a.

Kumar, R., Barth, M. C., Madronich, S., Naja, M., Carmichael, G. R., Pfister, G. G., Knote, C., Brasseur, G. P., Ojha, N., and Sarangi, T.: Effects of dust aerosols on tropospheric chemistry during a typical pre-monsoon season dust storm in northern India, Atmos. Chem. Phys., 14, 6813-6834, doi:10.5194/acp-146813-2014, 2014b.

Kumar, R., Barth, M. C., Pfister, G. G., Nair, V. S., Ghude, S. D., and Ojha, N.: What controls the seasonality of cycle of BC in India?, J. Geophys. Res., submitted, 2015. 
Lau, K. M., Kim, M. K., and Kim, K. M.: Asian summer monsoon anomalies induced by aerosol direct forcing: The role of the Tibetan Plateau, Clim. Dynam., 26, 855-864, doi:10.1007/s00382006-0114-z, 2006.

Lawrence, M. G. and Lelieveld, J.: Atmospheric pollutant outflow from southern Asia: a review, Atmos. Chem. Phys., 10, 1101711096, doi:10.5194/acp-10-11017-2010, 2010.

Lu, Z. and Streets, D. G.: The Southeast Asia Composition, Cloud, Climate Coupling Regional Study Emission Inventory, available at: http://bio.cgrer.uiowa.edu/SEAC4RS/html/ (last access: 12 May 2015), 2012.

Lu, Z., Zhang, Q., and Streets, D. G.: Sulfur dioxide and primary carbonaceous aerosol emissions in China and India, 1996-2010, Atmos. Chem. Phys., 11, 9839-9864, doi:10.5194/acp-11-98392011, 2011.

Marrapu, P., Cheng, Y., Beig, G., Sahu, S., Srinivas, R., and Carmichael, G. R.: Air quality in Delhi during the Commonwealth Games, Atmos. Chem. Phys., 14, 10619-10630, doi:10.5194/acp-14-10619-2014, 2014.

Menon, S., Koch, D., Beig, G., Sahu, S., Fasullo, J., and Orlikowski, D.: Black carbon aerosols and the third polar ice cap, Atmos. Chem. Phys., 10, 4559-4571, doi:10.5194/acp-10-4559-2010, 2010.

Moorthy, K. K., Satheesh, S. K., and Babu, S. S.: Integrated Campaign for Aerosols, Gases and Radiation Budget (ICARB): An overview, J. Earth Sys. Sci., 117, 243-262, 2008.

Moorthy, K. K., Beegum, S. N., Srivastava, N., Satheesh, S. K., Chin, M., Bond, N., Babu, S. S., and Singh, S.: Performance evaluation of chemistry transport models over India, Atmos. Environ., 71, 210-225, doi:10.1016/j.atmosenv.2013.01.056, 2013.

Morrison, H., Thompson, G., and Tatarskii, V.: Impact of Cloud Microphysics on the Development of Trailing Stratiform Precipitation in a Simulated Squall Line: Comparison of One- and TwoMoment Schemes, Mon. Weather Rev., 137, 991-1007, 2009.

Nair, V. S., Babu, S. S., and Moorthy, K. K.: Aerosol characteristics in the marine atmospheric boundary layer over the Bay of Bengal and Arabian Sea during ICARB: Spatial distribution and latitudinal gradients, J. Geophys. Res., 113, D15208, doi:10.1029/2008JD009823, 2008.

Nair, V. S., Solmon, F., Giorgi, F., Mariotti, L., Babu, S. S., and Moorthy, K., K.: Simulation of South Asian aerosols for regional climate studies, J. Geophys. Res., 117, D04209, doi:10.1029/2011JD016711, 2012.

Nair, V. S., Babu, S. S., Moorthy, K. K., Sharma, A. K., and Ajai, A. M.: Black carbon aerosols over the Himalayas: direct and surface albedo forcing, Tellus B, 65, 19738, doi:10.3402/tellusb.v65i0.19738, 2013.

Neu, J. L. and Prather, M. J.: Toward a more physical representation of precipitation scavenging in global chemistry models: cloud overlap and ice physics and their impact on tropospheric ozone, Atmos. Chem. Phys., 12, 3289-3310, doi:10.5194/acp-12-32892012, 2012.

Pathak, B., Kalita, G., Bhuyan, K., Bhuyan, P. K., and Moorthy, K. K.: Aerosol temporal characteristics and its impact on shortwave radiative forcing at a location in the northeast of India, J. Geophys. Res.-Atmos., 115, D19204, doi:10.1029/2009jd013462, 2010.

Pfister, G. G., Avise, J., Wiedinmyer, C., Edwards, D. P., Emmons, L. K., Diskin, G. D., Podolske, J., and Wisthaler, A.: CO source contribution analysis for California during ARCTAS-CARB, Atmos. Chem. Phys., 11, 7515-7532, doi:10.5194/acp-11-75152011, 2011.

Pöschl, U.: Atmospheric aerosols: composition, transformation, climate and health effects, Angew. Chem. Int. Ed., 44, 7520-7540, 2005.

Ram, K., Sarin, M. M., and Tripathi, S. N.: A 1 year record of carbonaceous aerosols from an urban site in the Indo-Gangetic Plain: Characterization, sources and temporal variability, J. Geophys. Res.- Atmos., 115, D24313, doi:10.1029/2010jd014188, 2010.

Ramanathan, V. and Carmichael, G.: Global and regional climate changes due to black carbon, Nat. Geosci., 1, 221-227, 2008.

Ramanathan, V., Chung, C., Kim, D., Bettge, T., Buja, L., Kiehl, J. T., Washington, W. M., Fu, Q., Sikka, D. R., and Wild, M.: Atmospheric Brown Clouds: Impacts on South Asian Climate and Hydrological Cycle, P. Natl. Acad. Sci. USA, 102, 53265333, 2005.

Reddy, M. S., Boucher, O., Balkanski, Y., and Schulz, M.: Aerosol optical depths and direct radiative perturbations by species and source types, Geophys. Res. Lett., 32, L12803, doi:10.1029/2004GL021743, 2005.

Satheesh, S. K. and Ramanathan, V.: Large differences in tropical aerosol forcing at the top of the atmosphere and Earth's surface, Nature, 405, 60-62, 2000.

Skamarock, W. C., Klemp, J. B., Dudhia, J., Gill, D. O., Barker, D. M., Wang, W., and Powers, J. G.: A description of the advancedresearch WRF version 2, NCAR Tech. Note, NCAR/TN468+STR, Natl. Cent. for Atmos. Res., Boulder, Colo, available at: http://wrf-model.org/wrfadmin/publications.php (last access: 24 August 2014), 2008.

Srivastava, S., Lal, S., Venkataramani, S., Gupta, S., and Sheel, V.: Surface distributions of $\mathrm{O}_{3}, \mathrm{CO}$ and hydrocarbons over the Bay of Bengal and the Arabian Sea during pre-monsoon season, Atmos. Environ., 47, 459-467, 2012.

Tewari, M., Chen, F., Wang, W., Dudhia, J., LeMone, M. A., Mitchell, K., Ek, M., Gayno, G., Wegiel, J., and Cuenca, R. H.: Implementation and verification of the unified NOAH land surface model in the WRF model, 20th conference on weather analysis and forecasting/16th conference on numerical weather prediction, Boulder, USA, 22-25 June 2004, 11-15, 2004.

Tie, X., Madronich, S., Walters, S., Edwards, D. P., Ginoux, P., Mahowald, N., Zhang, R., Lou, C., and Brasseur, G.: Assessment of the global impact of aerosols on tropospheric oxidants, J. Geophys. Res., 110, D03204, doi:10.1029/2004JD005359, 2005.

Unger, N., Shindell, D. T., and Wang, S.: Climate forcing by the onroad transportation and power generation sectors, Atmos. Environ., 43, 3077-3085, doi:10.1016/j.atmosenv.2009.03.021, 2009.

Unger, N., Bond, T. C., Wang, J. S., Koch, D. M., Menon, S., Shindell, D. T., and Bauer, S.: Attribution of climate forcing to economic sectors, P. Natl. Acad. Sci., 107, 3382-3387, doi:10.1073/pnas.0906548107, 2010.

Verma, S., Venkataraman, C., and Boucher, O.: Attribution of aerosol radiative forcing over India during the winter monsoon to emissions from source categories and geographical regions, Atmos. Environ., 45, 4398-4407, 2011.

Wang, Q., Jacob, D. J., Spackman, J. R., Perring, A. E., Schwarz, J. P., Moteki, N., Marais, E. A., Ge, C., Wang, J., and Barrett, S. R. H.: Global budget and radiative forcing of black car- 
bon aerosol: Constraints from pole-to-pole (HIPPO) observations across the Pacific, J. Geophys. Res. Atmos., 119, 195-206, doi:10.1002/2013JD020824, 2014.

Wesely, M. L.: Parameterization of surface resistance to gaseous dry deposition in regional-scale numerical models, Atmos. Environ., 23, 1293-1304, doi:10.1016/0004-6981(89)90153-4, 1989.

Wiedinmyer, C., Akagi, S. K., Yokelson, R. J., Emmons, L. K., AlSaadi, J. A., Orlando, J. J., and Soja, A. J.: The Fire INventory from NCAR (FINN): a high resolution global model to estimate the emissions from open burning, Geosci. Model Dev., 4, 625641, doi:10.5194/gmd-4-625-2011, 2011.
Yasunari, T. J., Bonasoni, P., Laj, P., Fujita, K., Vuillermoz, E., Marinoni, A., Cristofanelli, P., Duchi, R., Tartari, G., and Lau, K.-M.: Estimated impact of black carbon deposition during premonsoon season from Nepal Climate Observatory - Pyramid data and snow albedo changes over Himalayan glaciers, Atmos. Chem. Phys., 10, 6603-6615, doi:10.5194/acp-10-6603-2010, 2010.

Zaveri, R., Easter, R., Fast, J., and Peters, L.: Model for simulating aerosol interactions and chemistry (MOSAIC), J. Geophys. Res., 113, D13204, doi:10.1029/2007JD008782, 2008.

Zhang, X., Y., Wang, Y. Q., Zhang, X. C., Guo, W., and Gong, S. L.: Carbonaceous aerosol composition over various regions of China during 2006, J. Geophys. Res.-Atmos., 113, D14111, doi:10.1029/2007jd009525, 2008. 